\title{
Antimicrobial Effect of Silver Nanoparticles Synthesised with Ocimum Sanctum Leaf Extract on Periodontal Pathogens
}

\author{
Sirisha $\mathrm{P}^{1}$, Gayathri $\mathrm{GV}^{2 *}$, Dhoom $\mathrm{SM}^{3}$ and Amulya $\mathrm{KS}^{4}$ \\ ${ }^{1}$ Former Post graduate student, Department of Periodontics, Bapuji Dental College and Hospital, Davangere, Karnataka, India \\ ${ }^{2}$ Professor, Department of Periodontics, Bapuji Dental College and Hospital, Davangere, Karnataka, India \\ ${ }^{3}$ Head of Department, Department of Periodontics, Bapuji Dental College and Hospital, Davangere, Karnataka, India \\ ${ }^{4}$ Post graduate student, Department of Periodontics, Bapuji Dental College and Hospital, Davangere, Karnataka, India
}

*Corresponding author: Gayathri GV, Professor, Department of Periodontics, Bapuji Dental College and Hospital, Davangere, Karnataka, India, Tel: 09886593224, Email: gayathri_dental@rediffmail.com

Citation: Sirisha P, Gayathri GV, Dhoom SM, Amulya KS (2017) Antimicrobial Effect of Silver Nanoparticles Synthesised with Ocimum Sanctum Leaf Extract on Periodontal Pathogens. J Oral Health Dent Sci 1: 106

Article history: Received: 24 September 2017, Accepted: 05 November 2017, Published: 07 November 2017

\begin{abstract}
Nano silver particles have been widely used in biomedical applications for diagnosis and treatment. Green synthesis of nanoparicles by using Ocimum sanctum results in rapid, economical and ecofriendly product for drug delivery. The minimum inhibitory concentration and minimum bactericidal concentration tests detected the antimicrobial action of pure Ocimum sanctum extract (OSE), silver nitrate (SN), and silver nanoparticles synthesized with OSE (AgNP) against four periodontal pathogens i.e., Fusobacterium nucleatum (Fn), Porphyromonas gingivalis (Pg), Aggregatibacter actinomycetemcomitens (Aa) and Prevotella intermedia (Pi). The results suggest that, all the test solutions reveal their sensitivity to test microorganism in a dose dependent manner. Hence, increase in the concentration may improve their antimicrobial action. On comparision AgNP found to have an enhanced antimicrobial activity and Aa found to be more susceptible for the same.
\end{abstract}

Keywords: Silver nanoparticles; Ocimum sanctum; Periodontal pathogens; MIC - MBC

\section{Introduction}

Chronic periodontitis (CP) is considered as one of the most common oral infection caused by invasion of microbes and the subsequent host microbe interactions which, if unimpeded can ultimately result in tooth mobility and culminate in the grim fate of tooth loss [1]. There is evidence convicting Aggregatibacter actinomycetemcomitans (Aa), porphyromonas gingivalis (Pg), prevotella intermedia (Pi) and fusobacterium nucleatum (Fn), capnocytophaga and wolionella species as causative agents for periodontal diseases [2].

Previously mechanical therapy alone was acknowledged as the sole effective treatment for the disease but due to inaccessibility of instruments into deep periodontal pockets and tissue invasive nature of pathogens proved it as less efficacious mode of treatment $[3,4]$. To overcome this, systemic antimicrobial therapy was used as an adjunct with mechanical therapy, which proved to be a successful treatment regimen for periodontitis [5,6]. However, many unintended effects of antibiotics which range from hypersensitivity reactions, antibiotic resistance and suppression of normal flora were observed [7-9]. This increased the interest of clinicians in the direction of substituting herbs as an adjunct to mechanical therapy. The natural phytochemicals present in herbs offer an effective alternative to antibiotics and represent a promising approach in the prevention and therapeutic strategies of oral infections.

Various herbs like Acacia catechu (Cutch tree), Aloe indica Royle (Indian Aloe), Azadiracta indica (Neem), Curcuma longa (Turmeric) and Punica granatum (Pomegranate) have been tested successfully for their antibacterial activity against periodontal pathogens [10,11]. Among them Ocimum sanctum (holy basil or Tulsi) which is known as the "Queen of herbs" found to be safe, inexpensive, tremendously effective and culturally acceptable. It has long been employed in hundreds of different formulations for the treatment of wide range of disorders, including those affecting the mouth, throat, lungs, heart, blood, liver, kidney, and the digestive, metabolic, reproductive and nervous systems [12]. Studies reveal that Ocimum has a unique combination of actions that 
include: Antimicrobial, anti-oxidant, anti-inflammatory, chemopreventive, radioprotective, analgesic, anti-pyretic, anti-allergic, immunomodulatory, adaptogenic, anti-stress, anti-leukodermal and anti-coagulant activities [13].

The antimicrobial efficacy of Ocimum has been tested against number of pathogenic microorganisms namely Streptococcus mutans, Staphylococcus aureus, Candida albicans, enteric pathogens, Kliebsiella, Escherichia coli, Proteus, multi resistant strains of Neisseria gonorrhea and beta lactamase producing methicillin - resistant strains of Staphylococcus aureus. The antimicrobial effect of Ocimum sanctum was mainly attributed to the presence of eugenol (1-hydroxy-2-methoxy-4-allylbenzene), ursolic acid and carvacrol $[11,14,15]$.

Silver is known for possessing an inhibitory effect toward many bacterial strains \& microorganisms [16]. In medicines, silver has a wide application in skin ointments to prevent infection in burns and open wounds. Even medical devices \& implants were prepared with silver impregnated polymers [17].

Recently metal nanoparticles (NP) are gaining the interest of researchers due to their distinctive potential which have applications in the field of electronic, magnetic, opto-electronic, information storage and drug delivery [18-22]. Nanotechnology in dentistry involves applications of NPs in local anesthesia, nanocomposites, oral cancer treatment, bone grafts, surface treatment for implants [23]. NPs have been synthesised with the help of metal ions like silver, gold, palladium, zinc and nickel; using physical, chemical, biological (green) methods. Among them, silver nanoparticles (AgNPs) are efficient non-specific antimicrobial agents against planktonic forms of a broad spectrum of bacterial, fungal and viral species [24]. Their antimicrobial activities were attributed to the unique physicochemical characteristics, such as the high ratio of surface area to mass, high reactivity, and nanometer sizes [25].

The physical and chemical techniques in the synthesis of NPs involve several hazardous chemicals like sodium dodecyl benzyl sulfate or polyvinyl pyrrolidone or high energy requirements, which are toxic and wasteful [26]. A greener approach, in which the synthesis of NPs clubbed with herbal products has resulted in simple, one-step, cost-effective and environmental friendly products [27].

Minimum inhibitory concentrations (MIC) test confirms the susceptibility / resistance of microorganisms to an antimicrobial agent and Minimum bactericidal concentration (MBC) test determines of the minimum concentration of an antimicrobial agent necessary to achieve bactericidal effect. Both these tests can be good but relatively expensive tools to rank new antimicrobial agents by potency for screening purposes.

A large no. of plants have been used for synthesis of AgNPs. To our knowledge, no study has been conducted to know the antibacterial activity of AgNPs synthesised using Ocimum leaf extract on the most common periodontal pathogens. Hence the aim of the present study was to find out the MIC and MBC of AgNPs synthesised using Ocimum leaf extract on specific periodontal pathogens like $\mathrm{Fn}, \mathrm{Pg}, \mathrm{Aa}$ and $\mathrm{Pi}$ and to compare it with MIC and MBC of pure ocimum leaf extract and silver nitrate solution.

\section{Main body}

\section{Preparation of pure Ocimum sanctum leaf extract solution}

Fresh leaves of Ocimum sanctum were collected from surroundings of Tirupathi, Andhra Pradesh, India. $20 \mathrm{~g}$ of thoroughly washed finely chopped leaves of Ocimum sanctum were mixed in $100 \mathrm{ml}$ of distilled water and boiled for 5 min. The resultant extract was allowed to cool at room temperature and filtered with Whitman no. 1 filter paper. The extract was preserved at $4{ }^{\circ} \mathrm{C}$ in refrigerator.

\section{Preparation of pure Silver nitrate solution}

The AR (Analytical Reagent) grade silver nitrate powder $\left(\mathrm{AgNO}_{3}\right)$ was purchased from Sigma-Aldrich chemicals, Mumbai, India. $0.1 \mathrm{mM}$ solution was prepared by adding 16.98 milli grams of silver nitrate powder to one litre of distilled water. (One Mole of Silver Nitrate weighs 169.8 grams). The silver nitrate powder was added to the distilled water, and flask was swirled till it dissolves completely and the solution was stored at room temperature.

\section{Preparation of silver nanoparticles using Ocimum sanctum leaf extract}

$0.5 \mathrm{ml}$ of Ocimum sanctum extract was added to $10 \mathrm{ml}$ of $1 \mathrm{mM} \mathrm{AgNO}$ aqueous solution for bio-reduction process. The Ocimum sanctum fresh leaf extract was used for the reduction of silver cations to silver atoms. The change in the colour from transparent to dark yellow indicates the synthesis of nanoparticles.

\section{Bacterial strains}

Bacterial strains used in this study were American type culture collection, Manassas, VA, USA. The tested bacterial strains in this study were Fusobacterium nucleatum ATCC 25586, Porphyromonas gingivalis ATCC 33277, Aggregatibacter actinomycetocomitans ATCC 29523 and Prevotella intermedia ATCC 25611.

\section{Preparation of bacterial suspension}

The required organisms ( $F n, P g, A a$ and $P i)$ were sub-cultured from the stock cultures and then $10 \mu \mathrm{l}$ of each was added into $2 \mathrm{ml}$ 
of Thioglycollate broth. For standardization, the selected test bacterial strains were adjusted for 0.5 McFarland turbidity standards $\left(10^{-8}\right.$ colony forming units $\left./ \mathrm{ml}\right)$.

\section{Antibacterial activity}

Antibacterial activity was determined by conducting Minimum inhibitory concentration (MIC) and Minimum bactericidal concentration (MBC) test for all the three test solutions; i.e. pure ocimum extract (OSE), pure silver nitrate (SN) and silver nanoparticles synthesised with Ocimum extract (AgNP).

\section{Statistical analysis}

For MIC: the sensitivity(S) or resistance (R) of each test microorganism (Fn, $P g, A a$ and $P i$ ) against the three test solutions (OSE, $\mathrm{SN}, \mathrm{AgNP}$ ) with a concentration ranging between 0.2 to $100 \mu \mathrm{g} / \mathrm{ml}$ was tabulated (Table 1 ). The lowest concentration of a test solution without turbidity was considered as MIC of that solution against microorganism.

\begin{tabular}{|c|c|c|c|c|c|c|c|c|c|c|c|c|}
\hline \multirow{2}{*}{$\begin{array}{c}\text { Serial } \\
\text { dilutions } \\
(\mu \mathrm{g} / \mathrm{ml})\end{array}$} & \multicolumn{3}{|c|}{$F n$} & \multicolumn{3}{|c|}{$\mathrm{Pg}$} & \multicolumn{3}{|c|}{$A a$} & \multicolumn{3}{|c|}{$P i$} \\
\hline & OSE & SN & AgNP & OSE & SN & AgNP & OSE & SN & AgNP & OSE & SN & AgNP \\
\hline 100 & $S$ & $S$ & $S$ & $S$ & S & $S$ & S & S & $S$ & $S$ & $S$ & $S$ \\
\hline 50 & $\mathrm{R}$ & S & $S$ & $\mathrm{R}$ & S & S & $S$ & S & S & $\mathrm{R}$ & S & $S$ \\
\hline 25 & $\mathrm{R}$ & $S$ & $S$ & $\mathrm{R}$ & S & $S$ & $\mathrm{R}$ & $S$ & $S$ & $\mathrm{R}$ & $S$ & $S$ \\
\hline 12.5 & $\mathrm{R}$ & S & S & $\mathrm{R}$ & S & S & $\mathrm{R}$ & $\mathrm{R}$ & S & $\mathrm{R}$ & $S$ & S \\
\hline 6.25 & $\mathrm{R}$ & $S$ & $S$ & $\mathrm{R}$ & S & $S$ & $\mathrm{R}$ & $\mathrm{R}$ & S & $\mathrm{R}$ & S & $S$ \\
\hline 3.125 & $\mathrm{R}$ & $\mathrm{R}$ & $S$ & $\mathrm{R}$ & S & $S$ & $\mathrm{R}$ & $\mathrm{R}$ & $S$ & $\mathrm{R}$ & S & $S$ \\
\hline 1.5 & $\mathrm{R}$ & $\mathrm{R}$ & $S$ & $\mathrm{R}$ & $\mathrm{R}$ & $S$ & $\mathrm{R}$ & $\mathrm{R}$ & $\mathrm{R}$ & $\mathrm{R}$ & $S$ & $S$ \\
\hline 0.8 & $\mathrm{R}$ & $\mathrm{R}$ & $S$ & $\mathrm{R}$ & $\mathrm{R}$ & $S$ & $\mathrm{R}$ & $\mathrm{R}$ & $\mathrm{R}$ & $\mathrm{R}$ & $S$ & $S$ \\
\hline 0.4 & $\mathrm{R}$ & $\mathrm{R}$ & $S$ & $\mathrm{R}$ & $\mathrm{R}$ & $\mathrm{R}$ & $\mathrm{R}$ & $\mathrm{R}$ & $\mathrm{R}$ & $\mathrm{R}$ & $\mathrm{R}$ & $S$ \\
\hline 0.2 & $\mathrm{R}$ & $\mathrm{R}$ & $\mathrm{R}$ & $\mathrm{R}$ & $\mathrm{R}$ & $\mathrm{R}$ & $\mathrm{R}$ & $\mathrm{R}$ & $\mathrm{R}$ & $\mathrm{R}$ & $\mathrm{R}$ & $\mathrm{R}$ \\
\hline
\end{tabular}

OSE: ocimum sanctum extract; SN: silver nitrate; AgNP: silver nanoparticles synthesised with ocimum extract; R: Resistant; S: Sensitive; Fn: Fusobacterium nucleatum; Pg: Porphyromonas gingivalis; Aa: Aggregatibacter actinomycetemcomitans; Pi: Prevotella intermedia Table 1: MIC of test solutions

For MBC: the colony forming units of each test microorganisms ( $F n, P g, A a$ and $P i$ ) against the three test solutions (OSE, SN, AgNP) with a concentration ranging between 0.2 to $100 \mu \mathrm{g} / \mathrm{ml}$ was tabulated (Table 2). No growth of microorganisms was considered as bactericidal and growth was considered as bacteriostatic.

\begin{tabular}{|c|c|c|c|c|c|c|c|c|c|c|c|c|}
\hline \multirow{2}{*}{$\begin{array}{c}\text { Serial } \\
\text { dilutions } \\
\boldsymbol{\mu} / \mathbf{m} \mathbf{m}\end{array}$} & \multicolumn{3}{|c|}{$F n(\mathrm{CFU} / \mathrm{ml})$} & \multicolumn{3}{c|}{$P g(\mathrm{CFU} / \mathrm{ml})$} & \multicolumn{3}{c|}{$A a(\mathrm{CFU} / \mathrm{ml})$} & \multicolumn{3}{c|}{$P i(\mathrm{CFU} / \mathrm{ml})$} \\
\cline { 2 - 16 } & OSE & SN & AgNP & OSE & SN & AgNP & OSE & SN & AgNP & OSE & SN & AgNP \\
\hline $\mathbf{1 0 0}$ & 32 & NG & 28 & 48 & 8 & 34 & NG & 52 & NG & NG & 54 & 48 \\
\hline $\mathbf{5 0}$ & 49 & NG & 30 & 54 & 20 & 39 & 34 & 60 & NG & 60 & 58 & 59 \\
\hline $\mathbf{2 5}$ & 52 & NG & 39 & 76 & 27 & 43 & 42 & 62 & NG & 78 & 62 & 70 \\
\hline $\mathbf{1 2 . 5}$ & 58 & NG & 54 & 79 & 30 & 49 & 48 & 70 & NG & 84 & 99 & 74 \\
\hline $\mathbf{6 . 2 5}$ & 83 & 54 & 68 & 89 & 32 & 54 & 50 & 78 & NG & 96 & 102 & 98 \\
\hline $\mathbf{3 . 1 2 5}$ & 103 & 62 & 74 & 90 & 76 & 60 & 68 & 88 & NG & 128 & 124 & 113 \\
\hline $\mathbf{1 . 5}$ & 136 & 78 & 83 & 96 & 89 & 69 & 74 & 94 & 13 & 154 & 126 & 126 \\
\hline $\mathbf{0 . 8}$ & 142 & 80 & 90 & 103 & 96 & 72 & 98 & 93 & 18 & 186 & 130 & 134 \\
\hline $\mathbf{0 . 4}$ & 182 & 93 & 103 & 105 & 104 & 89 & 113 & 102 & 20 & 206 & 132 & 148 \\
\hline $\mathbf{0 . 2}$ & 220 & 102 & 136 & 136 & 140 & 102 & 136 & 132 & 25 & 213 & 198 & 152 \\
\hline
\end{tabular}

OSE : ocimum sanctum extract; SN: silver nitrate; AgNP: silver nanoparticles synthesised with ocimum extract; CFU/ml : Colony forming units per milli litre; Fn: Fusobacterium nucleatum; Pg: Porphyromonas gingivalis; Aa: Aggregatibacter actinomycetemcomitans; Pi: Prevotella intermedia

Table 2: MBC of test solutions

\section{Minimum Inhibitory Concentrations (MIC) [28] (Table 1)}

For MIC 9 dilutions of OSE, SN, AgNP were prepared with thioglycolate broth medium. For $900 \mu$ l of TG broth, $100 \mu$ l of test solutions were added so that total volume of the first tube becomes $1000 \mu$. The resultant concentration becomes $100 \mu \mathrm{g}$ of test ingredient (OSE/ SN/ AgNP) in a $1000 \mu$ i.e. $100 \mu \mathrm{g} / \mathrm{ml}$ in the first tube. For serial dilutions, $500 \mu \mathrm{l}$ of TG broth was added into the next 9 test tubes separately. From the first tube $500 \mu$ of solution was added to second tube, whose concentration becomes 50 $\mu \mathrm{g} / \mathrm{ml}$. From second tube, $500 \mu \mathrm{l}$ of solution was added to third tube to dilute it to become $25 \mu \mathrm{g} / \mathrm{ml}$. Finally after 9 dilutions, the 
concentration in the $10^{\text {th }}$ tube become $0.2 \mu \mathrm{g} / \mathrm{ml}$. In this way, serial dilution ranging between $100 \mu \mathrm{g} / \mathrm{ml}$ to $0.2 \mu \mathrm{g} / \mathrm{ml} \mathrm{was} \mathrm{prepared} \mathrm{for}$ 3 test ingredients. To each serially diluted tube, $200 \mu \mathrm{l}$ of previously prepared bacterial suspension was added and sealed air tightly to incubate at $37^{\circ}$ for 48 hours in an anerobic jar to observe turbidity. The tube which did not show any turbidity was considered sensitive $(\mathrm{S})$ and which showed turbidity as resistance $(\mathrm{R})$. The turbidity in each tube was compared with a positive control which contained only the bacterial suspension. This procedure was repeated for each test solution against each test microorganisms.

The MIC in $\mu \mathrm{g} / \mathrm{ml}$ of pure ocimum sanctum extract (first numbers), pure silver nitrate (second numbers) and silver nanoparticles synthesised with ocimum extract (third numbers) against the four bacterial species were as follows; $F n(100.0,6.25,0.40), P g(100.0$, 3.13, 0.80), $A a(50.0,25.0,3.13)$ and $P i(100.0,0.80,0.40)$.

\section{Minimum Bactericidal Concentration (MBC) [28] (Table 2) (Figure 1)}

After the MIC procedure, all the serially diluted tubes of test solutions were inoculated in culture plates containing TG broth medium. To overcome the procedural errors, inoculation was done in 5 segments of culture plate by using loop as series of parallel lines.

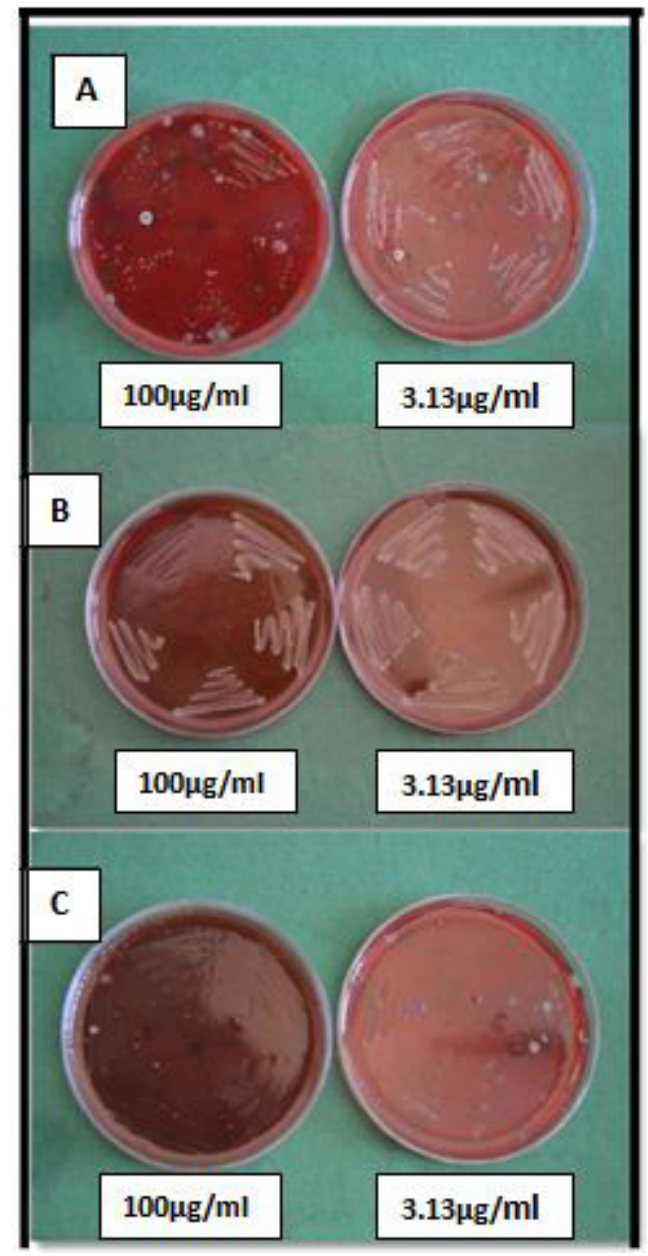

A. Ocimum sanctum extract (OSE); B. silver nitrate (SN); C. Silver nanoparticles synthesised with Ocimum sanctum (AgNP); Aa : Aggregatibacter actinomycetemcomitans

Figure 1: Shows the Minimum Bactericidal Concentrations of OSE, SN, AgNP against Aa at $100 \mu \mathrm{g} / \mathrm{ml}$ (left column) and $3.13 \mu \mathrm{g} / \mathrm{ml}$ (right column).

The inoculated culture plates were incubated at $37^{\circ}$ for 48 hours in an anaerobic jar. The bacterial colonies were counted by using digital colony counter (Sunshine Instruments, Electronics India ${ }^{\circledR}$, India). MBC was performed to know whether the test solution has bactericidal or bacteristatic effect against the test microorganism. The growth or non-growth of microorganism in minimum of 3 segments was considered to decide the $\mathrm{MBC}$ result. If there was no growth, then it was interpreted as bactericidal and if there was growth then as bacteriostatic.

The $\mathrm{MBC}$ in $\mu \mathrm{g} / \mathrm{ml}$ of pure ocimum sanctum extract (first numbers), pure silver nitrate (second numbers) and silver nanoparticles synthesized with ocimum extract (third numbers) against the four bacterial species were as follows; Fn (bacteriostatic, 12.5, bacteriostatic), $P g$ (bacteriostatic, bacteriostatic, bacteriostatic), $A a$ (100.0, bacteriostatic, 3.13) and $P i$ (100.0, bacteriostatic, bacteriostatic). The control sample did not affect the growth of microorganism. 
Efficient drug delivery system provides better bioavailability of therapeutic agents to targeted sites with reduced dosing frequency and side effects to produce adequate local and systemic effects. Hence encapsulation of antimicrobial drugs in nanoparticle system emerges as an innovative \& promising alternative that brings an enhanced therapeutic effectiveness \& minimize undesirable effects of drugs [29].

Anti-bacterial activity of organic solvents (ethanolic extract) of Ocimum sanctum found to be better than the aqueous extract due to enhanced secondary metabolite solubility [30]. However, reducing sugars which convert silver ions to silver nanoparticle are present only in aqueous extracts of O.sanctum. This also contains biological molecules like proteins \& terpenoids which perform dual functions of formation \& stabilization of silver. Hence aqueous extract of O.sanctum has been used to synthesise AgNPs [31].

Ocimum sanctum leaves extract showed increasing zones of inhibition with increasing concentration against $\mathrm{Aa}, \mathrm{Pg} \& \mathrm{Pi}$. Wide inhibition zones were observed at $5 \%$ and $10 \%$ concentrations and minimal zone of inhibition was observed with $0.5 \%, 1 \%$ and $2 \%$ [32]. Even in our study reduction in the number of colony forming units of test micro-organisms was observed in a dose dependent manner. Ocimum sanctum showed its antimicrobial efficiency as comparable to doxycycline at a concentration of 5\% and 10\% [32]. In this study the ocimum extract showed better antimicrobial action against $A a$. This is in accordance with the previous study, in which Ocimum sanctum was more effective against $A a$ than $P g$ and $P i$ [32].

Silver is an oxygen charged aqueous media which catalyzes the complete destructive oxidation of microorganisms [33]. Thus, silver ions, as an antibacterial component has been used in formulation of nanoparticles.

When bacterial cell was attacked by silver ions of silver nitrate solution, it causes detachment of the cytoplasmic membrane from the cell wall \& stimulates proteins which conglomerate and these proteins surround the nuclear region to protect DNA molecule. When this defensive mechanism fails, the cell wall will be penetrated by silver ions and nucleus will be attacked by them leading to death of a cell. Sometimes, interaction of silver ions with thiol group proteins may inactivate the enzyme activity to express their bactericidal activity [34].

AgNPs formed due to sunlight induction produced best results at 7\% concentration against all test bacteria [35]. In our study, bactericidal activity of silver nanoparticles exhibited only against $A a$ even at a concentration of $3.125 \mu \mathrm{g} / \mathrm{ml}$.

Addition of Ocimum sanctum leaf extract to silver nitrate solution results in colour change from transparent/light yellow to dark brown colour. This change is due to the excitation of surface plasmon resonance which indicates the production of silver nanoparticles [36]. Fourier transform infrared spectroscopy analysis of AgNPs confirmed the presence of carbonyl group of amino acid residues which act as a reducing and stabilizing agent due to their strong binding ability with metal [37,38]. Approximately 12 hours are usually required in plant mediated nano particle synthesis. Ocimum sanctum leaf extract could reduce silver ions into crystalline silver nanoparticles within 8 minutes due to the presence of potent antioxidants [38]. Shape, size and distribution of silver NPs can be controlled by adjusting reaction conditions like amount of plant extract, temperature, $\mathrm{pH}$, reaction time, concentration of metal salts and by employing different synthetic methods $[27,38]$. Under transmission electron microscope, the average size of AgNPs synthesized with Ocimum have been found to be ranged between 4- $30 \mathrm{~nm}[26,38]$.

Electrochemical analysis showed higher affinity of silver to react with phosphorous and sulphur compounds [34]. The cell membrane and interior of bacteria contains many sulphur containing proteins and phosphorous containing DNA [39]. Once silver nanoparticles comes in contact with the bacterial cell membrane, it increases its permeability and damage DNA which affects the respiratory chain, cell division and release silver ions inside the bacteria to enhance their bactericidal effect and finally causes the death of the cell [34].

The gram negative microorganisms are found to be more susceptible to the antibacterial activity of silver nanoparticles than gram positive ones due to thin, less rigid and more porous cell wall $[38,40]$. Contrary to this finding, silver nano particle synthesized with Ocimum sanctum by sunlight induction revealed more pronounced activity on gram positive Staphylococcus aureus, Staphylococcus epidermidis and Listeria monocytogenesis than on gram negative bacteria like Salmonella typhimurium, Escherichia coli, Pseudomonas aeruginosa and Pantoea ananatis [35]. The green synthesis of silver nanoparticle using Ocimum with methanol solvent gave high \& similar antibacterial activity against both gram positive \& gram negative bacteria [41]. Silver nanoparticle synthesized with Ocimum tenuflorum showed maximum antibacterial activity against spore forming B. substilus followed by gram positive Corney bacterium and gram negative E. coli respectively. This variation was attributed to the susceptibility of the organisms to variable synthetic methods [42].

Antimicrobial assay of silver nanoparticle on gram positive (S. aureus) and gram negative (E. coli) microorganism at different concentrations showed strong dose dependent activity [38]. Similarly even in our study, reduction in colony forming units of four gram negative test bacteria was observed on increase in the concentration of silver nano particle solution.

Silver nitrate showed better antibacterial activity than Ocimum sanctum extract, which is supported by a study where silver nitrate killed the bacteria efficiently from a range of $6 \times 10^{8}-1.5 \times 10^{9} \mathrm{CFU}$ to $0.5 \times 10^{2}-1.5 \times 10^{3}$. Though the leaf extract of Ocimum sanctum also could kill the bacteria but with lesser efficiency than the $10^{-3} \mathrm{M}$ silver nitrate solution [35].

Silver nanoparticle synthesized with Ocimum sanctum had enhanced antibacterial activity than the silver nitrate and pure Ocimum 
sanctum extract. In a study for both E. coli (Gram -ve) and S. aureus (Gram +ve), no zone of inhibition was observed by silver nitrate [43]. A small but noticeable zone of inhibition by Ocimum extract and a fairly significant antibacterial action was observed with AGNP's synthesized using Ocimum extract.

Hence, coupling of Ocimum extract with that of silver ions has proved to be beneficial to minimise the dose that needs to be administered for total microbial reduction.

\section{Conclusion}

MIC results of this study suggest that, all the test solutions were sensitive against test periodontopathogens at different concentrations. On comparison, silver nanoparticles synthesised with Ocimum extract has superior sensitivity against test microorganisms followed by Ocimum sanctum extract and silver nitrate solution respectively.

$\mathrm{MBC}$ results suggest that, all test solutions have bacteristatic potential on the test microorganisms in a dose dependent manner. Except $P g$, all the test micro-organisms $(A a, F n, \& P i)$ were found to be susceptible to the bactericidal action at different concentrations of test solutions. The numbers of colony forming units per milli litre were found to be increased as the concentration of test solutions reduced due to serial dilution. Hence increase in the concentration of test solutions may enhance their bactericidal potential.

Though invitro values of MIC, MBC may not hold good for invivo studies due to their inherent limitations, but they serve as a surrogate marker attempting to quantify the drug activity and to determine the clinical drug dosage.

In future, the preparation \& clinical application of the silver nanoparticle synthesised with Ocimum sanctum as a controlled local drug delivery (LDD) system in adjunct with the standard care may be a new pardigm for the management of chronic periodontitis. This might help us to overcome the side effects of synthetic drug usage and the current challenge of drug resistance.

\section{Acknowledgement}

The authors are thankful to Staff of Department of Physics, Sri Venkateshwara University, Tirupathi, Andhra Pradesh, India, for preparation of silver nanoparticles.

Dr. Kishore Bhat, Professor and Head, Department of Microbiology, Director, Department of Molecular Biology and Immunology, Maratha Mandal's NGH Institute of Dental Sciences and Research Centre, Belgaum, Karnataka, India for the support provided in conducting microbiological assays.

\section{Authors contribution}

Sirisha P designed and performed the experiments, Gayathri GV analysed, interpreted the data and wrote the manuscript, Dhoom SM conceived and supervised the project, Amulya KS analysed and interpreted the data.

All the authors discussed the results and reviewed the manuscript.

\section{References}

1. Darout IA (2014) Oral bacterial interactions in periodontal health and disease. J Dent Oral Hyg 6: 51-7.

2. Consensus report (1996) Periodontal diseases: pathogenesis and microbial factors. Ann Periodontol 1: 926-32.

3. Nordland P, Garrett S, Kiger R, Vanooteghem R, Hutchens LH, et al. (1987) The effect of plaque control and root debridement in molar teeth. J Clin Periodontol 14: 231-6.

4. Apatzidou DA, Kinane DF (2010) Nonsurgical mechanical treatment strategies for periodontal disease. Dent Clin North Am 54: 1-12.

5. Gusberti FA, Syed SA, Lang NP (1988) Combined antibiotic (metronidazole) and mechanical treatment effects on the subgingival bacterial flora of sites with recurrent periodontal disease. J Clin Periodontol 15: 353-9.

6. Carvalho LH, D’avila GB, Leao A, Goncalves C, Haffajee AD, et al. (2005) Scaling and root planing, systemic metronidazole and professional plaque removal in the treatment of chronic periodontitis in a Brazilian population II- microbiological results. J Clin Periodontol 32: 406-11.

7. Macy E, KY TP (2009) Self-reported antibiotic allergy incidence and prevalence: age and sex effects. Am J Med 122: 778.e1-7.

8. Ventola CL (2015) The antibiotic resistance crisis: part 1: causes and threats. P T 40: 277-83.

9. Edlund C, Nord CE (2000) Effect on the human normal microflora of oral antibiotics for treatment of urinary tract infections. J Antimicrob Chemother 46: 41-8. 10. Bhushan SK, Chauhan G, Disha N, Shobha P (2015) Treatment of Periodontal Disease - A Herbal Approach. Int. J. Pharm. Sci. Rev. Res 33: 126-36.

11. Palombo EA (2011) Traditional medicinal plant extracts and natural products with activity against oral bacteria: potential application in the prevention and treatment of oral diseases. Evid Based Complement Alternat Med. 2011: 680354

12. Mahajan N, Rawal S, Verma M, Poddar M, Alok S (2013) A phytopharmacological overview on Ocimum species with special emphasis on Ocimum sanctum. Biomed Prev Nutr 3: 185-92.

13. Pattanayak P, Behera P, Das D, Panda SK (2010) Ocimum sanctum Linn. A reservoir plant for therapeutic applications: An overview. Pharmacog rev 4: 95-105. 14. Shokeen P, Bala M, Sing M, Tandon V (2008) In vitro activity of eugenol, an active component from Ocimum sanctum, against multi resistant and susceptible strains of Neisseria gonorrhea. Int J Antimicrob Agents 32: 172-9.

15. Agarwal P, Nagesh L (2010) Evaluation of the antimicrobial activity of various concentrations of Tulsi (Ocimum sanctum) extract against Streptococcus mutans: An in vitro study. Indian J Den Res 21:357-9. 
16. Liau SY, Read DC, Pugh WJ, Furr JR, Russell AD (1997) Interaction of silver nitrate with readily identifiable groups: relationship to the antibacterial action of silver ions. Lett Appl Microbiol 25: 279-83.

17. Becker RO (1999) Silver ions in the treatment of local infections. Met Based Drugs 6: 311-4.

18. Cui Y, Lieber CM (2001) Functional nanoscale electronic devices assembled using silicon nanowire building blocks. Science 291: 851-3.

19. Tuutijärvi T, Lu J, Sillanpää M, Chen G (2009) As (V) adsorption on maghemite nanoparticles. J Hazard Mater 166: 1415-20.

20. Tanabe K (2007) Optical radiation efficiencies of metal nanoparticles for optoelectronic applications. Mater Lett 61: 4573-5.

21. Zhang HW, Liu Y, Sun SH (2010) Synthesis and assembly of magnetic nanoparticles for information and energy storage applications. Front Phy-Beijing 5: 34756.

22. Bhumkar DR, Joshi HM, Sastry M, Pokharkar VB (2007) Chitosan reduced gold nanoparticles as novel carriers for transmucosal delivery of insulin. Pharm Res 24: 1415-26.

23. Bhardwaj A, Bhardwaj A, Misuriya A, Maroli S, Manjula S, et al. (2014) Nanotechnology in dentistry: Present and future. J Int Oral Health 6: 121-6.

24. Kim JS, Kuk E, Yu KN et al (2007) Antimicrobial effects of silver nanoparticles. Nanomedicine 3: 95-110.

25. Martínez-Gutierrez F, Thi EP, Silverman JM, de Oliveira CC, Svensson SL, et al (2012) Antibacterial activity, inflammatory response, coagulation and cytotoxicity effects of silver nanoparticles. Nanomed Nanotechn Biol Med 8: 328-36.

26. Iravani S, Korbekandi H, Mirmohammadi SV, Zolfaghari B (2014) Synthesis of silver nanoparticles: chemical, physical and biological methods. Research Pharma Sci 9: 385-406.

27. Ahmed S, Ahmad M, Swami BL, Ikram S (2016) A review on plants extract mediated synthesis of silver nanoparticles for antimicrobial applications: a green expertise. J Adv Res 7: 17-28.

28. Schwalve, Moore, Goodwin (2007) Antimicrobial susceptibility testing protocols, Crc Press.

29. Zhang L, Pornpattananangku D, Hu CM, Huang CM (2010) Development of nanoparticles for antimicrobial drug delivery. Curr Med Chem 17: 585-94.

30. Sathyavathi R, Krishna MB, Rao SV, Saritha R, Rao DN (2010) Biosynthesis of silver nanoparticles using Coriandrum sativum leaf extract and their application in nonlinear optics. Adv Sci Lett 3: 138-43.

31. Rao YS, Kotakadi VS, Prasad TN, Reddy AV, Gopal DS (2013) Green synthesis and spectral characterization of silver nanoparticles from Lakshmi tulasi (Ocimum sanctum) leaf extract. Spectrochim Acta A Mol Biomol Spectrosc 103: 156-9.

32. Mallikarjun S, Rao A, Rajesh G, Shenoy R, Pai M (2016) Antimicrobial efficacy of Tulsi leaf (Ocimum sanctum) extract on periodontal pathogens: An in vitro study. J Indian Soc Periodontol 20: 145-50.

33. Davies RI, Etris SF (1997) Development and functions of silver in water-purification and disease-control. Catal Today.36: 107-14.

34. Feng QL, Wu J, Chen GQ, Cui FZ, Kim TN, et al. (2000) A mechanistic study of the antibacterial effect of silver ions on Escherichia coli and Staphylococcus aureus. J Biomed Mater Res 52: 662-8.

35. Brahmachari G, Sarkar S, Ghosh R, Barman S, Mandal NC, et al. (2014) Sunlight-induced rapid and efficient biogenic synthesis of silver nanoparticles using aqueous leaf extract of Ocimum sanctum Linn with enhanced antibacterial activity. Org Med Chem Lett 29: 18-25.

36. Mulvaney P (1996) Surface plasmon spectroscopy of nanosized metal particles. Langmuir 12: 788-800.

37. Fayaz AM, Balaji K, Girilal M, Yadav R, Kalaichelvan PT, et al. (2010) Biogenic synthesis of silver nanoparticles and their synergistic effect with antibiotics: a study against gram-positive and gram-negative bacteria. Nanomed Nanotecnol 6: 103-9.

38. Singhal G, Bhavesh R, Kasariya K, Sharma AR, Singh RP (2011) Biosynthesis of silver nanoparticles using Ocimum sanctum (Tulsi) leaf extract and screening its antimicrobial activity. J Nanopart Res 13: 2981-8.

39. Pommerville JC (2012) Alcamo's fundamentals of microbiology: Body systems ( $4^{\text {th }}$ Edn) Jones \& Bartlett Publishers.

40. Murray RG, Steed P, Elson HE (1965) The location of the mucopeptide in sections of the cell wall of Escherichia coli and other gram-negative bacteria. Can J Microbiol 11: 547-601.

41. Rout Y, Behera S, Ojha AK, Nayak PL (2012) Green synthesis of silver nanoparticles using Ocimum sanctum (Tulashi) and study of their antibacterial and antifungal activities. J Microbiol Antimicrob 4: 103-9.

42. Patil RS, Kokate MR, Kolekar SS (2012) Bioinspired synthesis of highly stabilized silver nanoparticles using Ocimum tenuiflorum leaf extract and their antibacterial activity. Spectrochim Acta A Mol Biomol Spectrosc 91: 234-8.

43. Ramteke C, Chakrabarti T,Sarangi BK, Pandey R (2013) Synthesis of silver nanoparticles from the aqueous extract of leaves of Ocimum sanctum for enhanced antibacterial activity. J Chem 2013: 278925. 